\title{
Freedom of Expression in The UK And Protection of Privacy in Human Rights: Princess Diana's Case As An Example
}

\author{
Araz Ramazan Ahmad \\ Department of Administration, College of Humanities, University of Raparin, Ranya, Kurdistan \\ Region, Iraq and Department of International relations \& Diplomacy, Faculty of Administrative \\ Sciences and Economics, Tishk International University, Erbil, Kurdistan Region, Iraq. \\ E-mail: Araz.ahmad85@gmail.com
}

\section{Nazakat Hussein Hamasaeed \\ Media Department, College of Humanities, University of Sulaimani, Sulaimani, Kurdistan Region, Iraq. \\ E-mail: nazakat.hamasaeed@univsul.edu.iq}

\section{Muhammad Saud}

Department of Sociology, Faculty of Social and Political Sciences, Universitas Airlangga, Indonesia.

E-mail: muhhammad.saud@gmail.com

\begin{abstract}
:
This paper mainly aims to argue the research questions "what is the right of privacy?, how the article 8 protected privacy in Act 1998 and to deliberate the case of princes Diana Between the freedom of expression and protect the privacy?. Hence, to discourse the impact of the media Law in dealing with freedom of expression and the right of privacy.

This paper will argues the concept of the Freedom of expression which is one of the most fundamental aspect of the individuals rights that enjoy in everyday life. It is fundamental to the existence of democracy and the respect of human dignity in the community. On the other hand, the paper will explore the impact on media law and some examples of rich figure, media celebrity and famous, which they complaining of the media invasion of privacy will be explained, and then how the Court treated with Princess Diana's case in the viewpoint of privacy and freedom of excretion concepts. The paper mainly depends on the content analysis method for analysing legal documentation of the articles related to the freedom of expression, also it depends on the case-study method for its sample which is Princess Diana's case.
\end{abstract}

Keywords: Freedom of Expression, UK, Privacy, Human Rights, Princess Diana. 


\subsection{Introduction}

This research depends on the content analysis method for analyzing legal documentation of the articles related to the freedom of expression, also it depends on the case-study method for its sample which is Princess Diana's case.

This paper includes sections explaining: Firstly, Human Rights and international human rights law. Secondly, the short history of the European Convention on Human Rights and fundamental freedoms in 1950. How the UK law adopted the Human Rights Act 1999/2000, Freedom of expression and privacy in the Human Rights Act 1998 article 10 and its content. Thirdly, it will discuss what the right to privacy is? How article 8 protected privacy in Act 1998. Besides, it will consider the more different ideas between the rights to privacy and Article the freedom of expression and Princess Diana's case as an example. Finally, the research will address the Impact on media law and explain some examples of rich and famous complaining of media invasion of privacy.

The knowledge and information of this paper work comes from many sources and documents which includes : A literature conducted through academic journals and databases, using the Library's Lit Search facility. In this paper mainly based on the views and shows of the resulted in articles and book references. Furthermore, this paper mainly focuses on the use of many books as resources which titled " McNae's, Essential Law for Journalists", "Freedom of Speech" and some other books, futher the researcher has used several online articles. Also, the researcher has used Online searching engine in order to report the case from various views of the different organizations, such as Human rights learning center: study guide on the European, Also, Columbia law: The European Human Rights System, the European Convention on Human Rights, and some others are used in the literature of the research too.

\subsection{Human Rights and International Human Rights law}

Human Rights are those we have by the good quality of being human, they are natural rights. Rights we own by natural, not by law (although they may be, and should be, protected by law) Serendipity (2020). The survival, strength, and the content of human rights continue to be subject to debate in philosophy and political science Euromedrights $(2020,23)$ but legally, "human rights are defined in international law and covenants, and further, in the domestic laws of many states. However, for many people, the principle of human rights goes beyond the law and forms a fundamental moral basis for regulation of the contemporary geopolitical order. For them, they are democratic ideals." (ibid).

International Human Rights law began as a response to the horrors of war, in particular, the World War 11 Law.cornell (2020) Although the Geneva conventions; the formation of the United Nations gave to the human rights concept international legitimacy, specially the key reason is the main nations has signed the United Nations charter which specifically mentions human rights (ibid).

Davies (1988) in his book referred to international human rights as" a right is the world's first universal ideology, religious, political, and economic ideas have an adherent in various parts of the world but human rights represent an idea that now has world-wide acceptance." Davies $(1988,1)$. The council of Europe believes that human rights "universal, invisible fundamental to all democratic societies" Council of Europe (2020,2) 


\subsection{European Convention on Human Rights}

The European continent suffered much devastation from the effects of World War 11. To renew efforts of peacekeeping and cooperation with one another after the war ended, leaders throughout the region founded three organizations: The Council of Europe, the European Union and afterward, the organization for security and cooperation in Europe Amnesty International (2014). Although these organization was founded to bring peace and stability to Europe, they were each established with a different purpose:

1- The council of Europe promotes the rule of law, human rights and democracy.

2- The European Union was devised as an institution for promoting trade and economic stability for its members.

3- The Organization for Security and Co-operation in Europe was founded to maintain peace and military security within Europe (ibid).

\subsection{The European Convention of Human Rights and fundamental freedoms in $\mathbf{1 9 5 0}$}

The European Convention on Human Rights and fundamental freedoms is a treaty signed in 1950 by the members of the council of Europe, so in this way, it predates the European communities and union, and arises from a quite different organization Nico Krisch. $(2007,22)$ two are linked; however, in that adherence to the convention is now effectively a condition of membership of Europe (ibid). The European Convention on Human Rights is not a product of the European Union and is not, directly at least, part of European community law; see Foster $(2003,29)$. Drafted soon after the end of the Second World War, in 1953 the UK was one of the first countries to signup to the convention; in which Articles 2 to 14 specify the rights that are protected currently over 45 countries are members Human Rights Program(2020)The European convention on human rights and fundamental freedoms is an original treaty, applicable to members of the councils of Europe, see Foster (2003).

"The UK was a founding member of the convention and was very influential in its design. It was amongst the first states to ratify the treaty" Nico Krisch. (2007,3). And it is an international treaty by which the member of the council of Europe sought to guarantee certain human rights and fundamental freedoms to that entire jurisdiction. It was signed in Rome on 4 November 1950, and came into force in independent bodies were originally set up to supervise the application of the right guaranteed in the convention; the European Commission of Human Rights and1950.European Court of Human Rights (1950). Council of Europe (2020)

\subsection{UK law and adopted the Human Rights Act 1999/2000.}

"The Human Rights Act 1998, which comes into force on 2 October, brings the European convention on Human Rights into British law and for the first time gave citizens specific legal rights, including the right to freedom of expression.", see Bank, Welsh, and Greenwood (2005,2). "Previously the rights of citizens were not guaranteed by statements of general principle as they are in some countries that have written constitution." (ibid). Requires all public authorities (including local authorities) to comply with the provisions of the convention and enables individuals to enforce convention right through the domestic courts in the UK Parlement.UK (2007).

The influence of the Convention has been growing in the UK in the past decade or so. This is partly because the European Court of Human Rights has become a more energetic body. But, more fundamentally, there has been a strong lobby within the UK for a written bill (statement) of rights, and the Convention is seen as a ready-made document for these purposes Nico Krisch. (2007). This idea has been adopted as the policy of the Labour government in 1997. Its ideas are set out in a White paper issued in October 1997, Rights Brought Home, see Foster 
(2003, 29) the Human Rights Bill (CM 3782London: HMSO), and then the Human Rights Bill (as introduced in the House of Lords on 23 October 1997) now passing throughout parliament and which is likely to come into force sometime in 1999 or perhaps 2000, (ibid). However the idea of citizens having rights in UK law did not begin with the Human Rights Bill, the recognition of rights in English law does have an ancient history going back to statements such as Mogna court 1215-95 and the Bill of Right of 1968, (ibid).

The second draft order, the International Seabed Authority (Immunities and privileges) order 2000 will enable the government to ratify the protocol on the privileges and immunities of the International Seabed Authority, which was published and presented to parliament in February again under cover of an explanatory memorandum Nico Krisch. (2007).

\subsection{Freedom of expression and privacy in Human right Act 1998}

"Freedom of expression is one of the most fundamental rights that individuals enjoy. It is fundamental to the existence of democracy and the respect of human dignity. "Amnesty International (2014,11). Bob Hepple QC has an article in Freedom of speech book which described freedom of expression as "the dog that did not bark in the development of UK law on harassment." Cripps and Beatson (2000,177). And he said" this silent dog may soon bite in the United Kingdoms as the incorporation by the Human rights Act 1998 of Article 10 on the European Convention of Human Rights into domestic law against harassment with freedom of expression, but this Account will need to be taken of other Convention rights such as freedom from degrading treatment, the right to respect for private life, and freedom from discrimination in the exercise of Convention right" see Cripps and Beatson (2000,177).

Consequently, the right of free speech is guaranteed by article 10 Act 1998 Human rights explained the right to freedom of expression in two sections. In section one when declared that "everyone has the right to freedom of expression" and in section 2 declared "The exercise of these freedoms, since it carries with it duties and responsibilities." Vickers $(2002,84)$. In this chapter 2 , the right to free speech was considered as of dual significance: fundamental personal freedom and an important political right and this is recognized by the European Convention of Human rights, see Vickers (2002). Correspondingly, (Araz, 2015) believes that the mass media could be a part to destroy public space of discourse they open up to grow the community and freedom of expression, and the freedom of expression can promote democracy through the media.

When discussed two sections of this article. "The right to freedom of expression is set out in section 1 of article 10 of the Convention, and it could equally well be called the right to freedom of information because it includes not only the right to hold opinions but also" to receive and impart information and ideas" without interference by public authority." Banks, Welsh and Greenwood (2005, 370). Before we started to discuss the contradiction between the freedoms of expression and protect privacy, we must explain what the Privacy is and what is the Human right act about Privacy.

\subsection{The right to privacy}

To discuss about the right of privacy, we started with the identity of Foster when in his book referred to" the general right to be let alone, a desire to be allowed to enjoy a particular space, either alone or with others, which the state or others should not be allowed to penetrate."See Foster (1003, 359). Article 8 of the European Convention provides that. "Everyone has the right to respect for his private and family life, his home and his correspondence, the article, has a horizontal effect, and the government and the courts have to protect these rights from violations by private individuals and complain." Foster $(1003,360)$. Privacy has been described as the right of the individual to be protected against interference into his personal life or affairs or those of his family, by direct physical means 
or by publications of information, see Banks, Welsh and Greenwood (2005).until 2 October 2000 the law of England did not specifically recognize the right to privacy, but on that date, Human right act 1998 came into force, in effect incorporating into English law the European Convention on Human rights, this guarantees under article 8 the right to privacy. (ibid)

\section{Between the freedom of expression and protect the privacy}

There are so many arguments and debates about two rights and what related or conflict between them. Where some people discussed and has argued that freedom of speech was a 'trump card' that always won! but An English judge has said" from the journalist's point of view it is encouraging to be told that freedom of speech is a trump card, but it is important to understand that this is subject to 'the established exceptions, such as the right to privacy, which need to be balanced, against the article 10 right." see Bank, Welsh and Greenwood (2005,371). Barendt refers to the necessity for free speech frame some people, perhaps a majority many argue that they are entitled to know, for example, whether a candidate for parliament or the presidency has committed marital infidelity, is secretly gay or beheaded disreputably as a university student twenty years ago, before deciding how to vote, Barendt (2005), while Lord Justice Sedley said "if freedom of expression is to be impeded it must be on convincing grounds recognized by law." see Bank, Welsh and Greenwood (2005,374). Besides, (Araz, 2019) states that censorship has negative impacts on freedom of expression and Media particularly in non-democratic countries consequently people do not have the freedom to speak and right to know then there is little divergence between democratic and autocratic systems.

This ground included, in article 10(2) the protection of the rights of others and these rights in turn included theatrical 8 right to privacy, see Bank, Welsh and Greenwood (2005). Foster referred to some point in his book about the legal and constitutional difficulties in the protection of the right to privacy and private life: "First it is necessary to define, privacy, and its boundaries to recognize its legal existence. Secondly, the law will need to determine the extent of the right to privacy and, more specifically, when it is legitimate to violate the right. Thirdly, even if domestic law decides to enact and develop the law of privacy, it will then need to achieve a balance between the enjoyment of that right and the protection of other individual rights and public interest." Foster (2003, 358).

Barendt said" the relationship of privacy and free speech (or press) rights is therefore complex." and he said "It would be wrong simply to apply the arguments relevant to offense without considering the extent to which the disclosure of private information is covered by freedom of speech." Barendt (2005). Mill's argument to conclude that "the public is entitled to know everything about everyone." Barendt $(2005,23)$. In Douglas case, Lord that will discuss in the next part Justice Sedley rejected the view that the section gave greater weight to freedom of expression than to privacy rights. He said" everything will ultimately depend on the proper balance between privacy and publicity in the situation facing court" see Bank, Welsh and greenwood (2005, 390) while "Journalists were concerned at the potential effect of the right to privacy on their freedom to publish true information of public interest." Bank, Welsh and Greenwood (2005,389).

Another argues about the content of the Article and protection against the media. The wording of article 8 suggests it gives protection for privacy against, public authority

the United Kingdom is a public authority and must take account of the judgment of the European Human right, see Bank, Welsh and Greenwood (2005). While Barendt argued with the question was not whether there was a public interest in the particular information being published, but whether, the public has an understandable and so a legitimate interest in being told the information, Barendt (2005). 
In the privacy code the Human Right act in section 12, privacy is one of the topics where there may be an exception to the rules set out in the code on grounds of public interest like" detection or exposing crime or serious impropriety and protecting public health and safety and preventing the public from being misinformed by an action or statement of an individual or organization" see Bank Welsh and Greenwood $(2005,392)$.

Another important thing is (PCC) the Press Complaints Commission, which ratified by the PCC on 07 August 2006 according to this code:" All members of the press have a duty to maintain the highest professional standards and this Code sets the benchmark for those ethical standards, protecting both the rights of the individual and the public's right to know." aws(2017) And also NUJ code" the NUJ launched a code of practice to address the important issues raised by the occurrence of 'citizen journalism' on (24/1/05), it will be known as the Witness Contributors' Code of Practice 'NUJ $(2007,3)$

\subsection{Example of privacy cases involving rich and famous.}

In the Douglas case, Lord Justice Sedley in the Court of Appeal declared:" it can be said with confidence that the law recognizes and will appropriately protect a right of personal privacy, and the Judge was speaking in cases in December 2000 in which the court was asked to lift a temporary injunction preventing a magazine from publishing, snatched, photographs of a wedding." See Bank, Welsh and Greenwood (2005, 389). When "two film stars, Michael Douglas and Catherine Zeta -Jones, had granted exclusive rights to picture of their wedding to the OK magazine! But the Hello magazine! Had its pictures, which is planned to, publish"(ibid). The judge decided that "they had won the case, but not on the grounds of privacy. He held the wedding was protected under the law of commercial confidence as a valuable trade asset and the publication of unauthorized photographs by a rival magazine was a breach of that confidence." See Bank, Welsh and Greenwood (2005,390). According to the breach, confidence law is based upon the principle that a person who has obtained information in confidence should not take unfair advantage of it. So in this case which OK Magazine was awarded more than £1 million in damage in 2003 after Hello Magazine published this picture of a wedding, see Bank,Welsh and Greenwood (2005) and The Scotsman (2020).

The judge considered clause 3 of the Press Complaints Commission code, relating to privacy, at the time in section 2 the code said:" the use of long lens photography to take pictures of people in a private place without their consent is unacceptable." see Bank, Welsh and Greenwood (2005,392) After a lengthy legal battle through several courts, Britain's highest court the House of Lords ruled at 12/6/2007 that Hello! Must pay $£ 20$ million in legal costs and damages Parlement.UK (2007). When the case of Princess Diana centered on photographs taken on the night the couple died, 31 August 1997 and Several European figures that saw Princess Diana as a victim of media competition urged the press to reflect on privacy issues surrounding celebrities The Insider (2020). Three photographers are to go on trial in a Paris court for taking pictures at the scene of the car crash that killed Princess Diana, Dodi AL Fayed, and their French driver Henri Paul in August 1997. They are charged with invasion of privacy, after an earlier attempt to prosecute them for manslaughter for failing to give assistance to the victims of an accident failed. And they could get up to one year in prison and a 45,000 Euro fine if they are found guilty (ibid).

In 2006, France's highest court found the photographers not guilty of having contributed to the crash, despite the paparazzo's high-speed pursuit of the car, and instead, a French investigation decided that the driver, Henri Paul, was to blame, driving too fast under the influence of alcohol and $a$ Paris court has acquitted three press photographers who took pictures of Princess Diana and boyfriend Dodi Al Fayed on the night of their fatal car crash six years ago, so Mr. Al Fayed whose son Dido was died instead pursued another legal option, this time using France's severe privacy laws Infotbel (2020). 
Although the verdict was welcomed by the photographers who have termed it a victory for the freedom of the press, but Mohamed AL Fayed has warned that he will appeal against the verdict, but in the same time, lawyers in Paris say they have seen no legal reason to overturn the judgment. Infotbel (2020) In a written summary of the judgment, the judge said" that even though the photos were taken inside the car, they had not shown any intimate gesture or behaviour between Diana and Dodi, and nor had they revealed any secret liaison as the relationship was already well known" (news.bbc.co.uk). The judge said "Diana and Al Fayed, would have been aware that photographers might take their picture as they left the hotel. "(ibid). "On 1 February 2001 the 'Mirror' newspaper carried as its first story on its front page a prominent article headed 'Naomi: I am a drug addict'. The article was supported on one side by a picture of Miss Campbell as a glamorous model, on the other side by a slightly indistinct picture of a smiling, relaxed Miss Campbell, dressed in baseball cap and jeans, over the caption 'Therapy: Naomi outside the meeting." Law.cornell $(2020,3)$

In 2004 the action by Naomi Campbell against the Daily Mirror went to the House of Lords. The Mirror had reported she had a drug addiction and that she was attending a meeting of Narcotics Anonymous and they secretly picture her emerging from one such meeting, and the judgments made the point that a picture taken in a public place of a private activity could be, confidential, and so its publication was a breach of Ms Campbell's right, see Bank, Welsh and Greenwood (2005) and Law.cornell (2020) Even "The PCC code used to say that use of long lens photography to take picture of people in private places without their consent was unacceptable." see Bank, Welsh and Greenwood $(2005: 408)$

\section{Conclusions and Results:}

The freedom of expression and privacy are crucial and important rights these days in most of the societies in the world and the deliberation on this issue continues, and we expect it to increase especially with the technology development and the complexity of contemporary world. Therefore, the law appears to be an efficient solution to the problems resulting from the incompatibility of two rights, and the court should be responsible for protecting them.

Although, some arguments tend to defend the importance of the above rights to the public interest, the information remains in general unnecessary to the public interest. To illustrate, the case involving Miss Campbell is a perfect example demonstrating that the publication of photography appears to be causing cogent damage to personal privacy, while publication of some of the information was held to be in the public interest but some others not. Despite the opinions which claim that everyone has the right to know the information especially about the rich and famous people, the courts must balance the freedom of speech and privacy, as a matter of fact in publishing photos, factors to take into account are whether the photo was taken of the claimant while he/she was in a public place or at home or in another private Place.

A further example is princes Diana's case. The paparazzi took pictures in a private place before and after the crash inside the car. Thus far, some people believe that Princess Diana was the victim of increasingly brutal and unscrupulous competition among the media. 


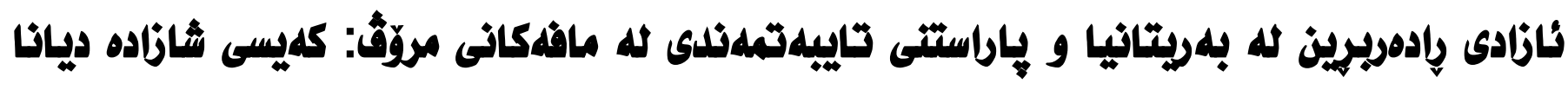 وهى نموونه}

\section{تُاراز رمضشاز احمد}

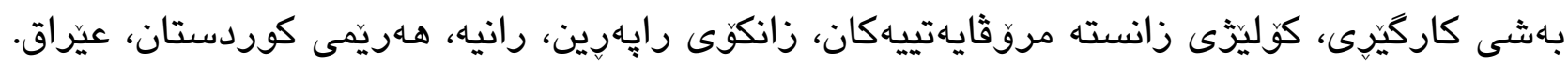

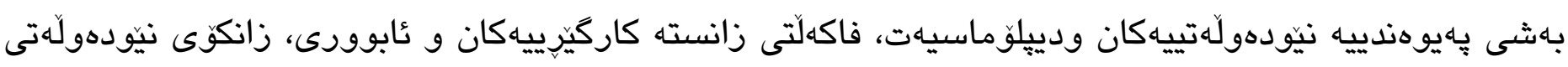

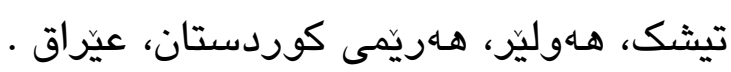
ئيمهل: : Araz.ahmad85@gmail.com

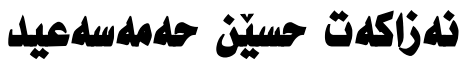

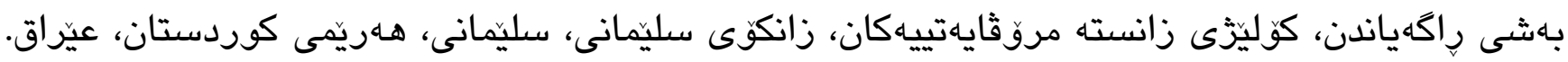

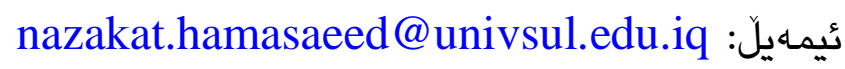

\section{مجمل سمود}

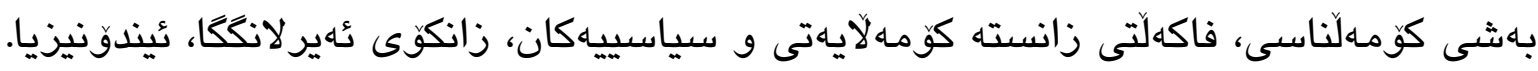

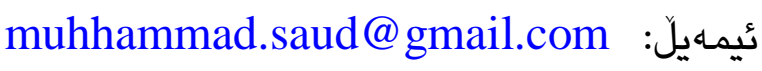

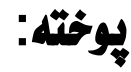

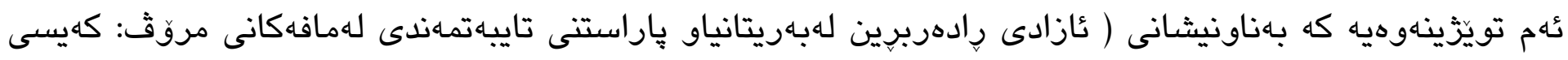

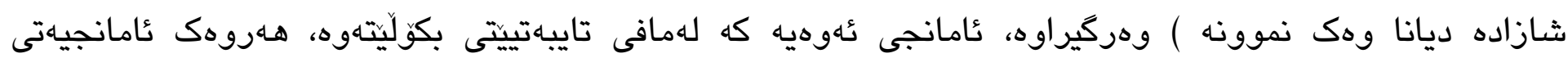

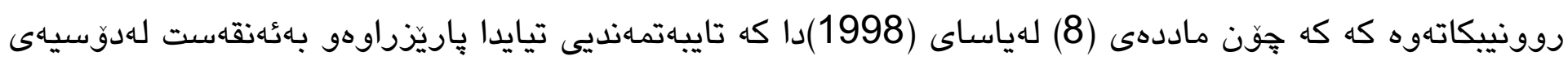

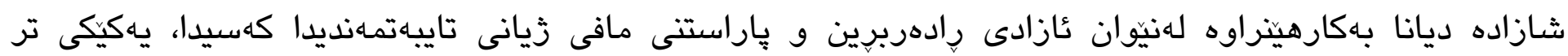

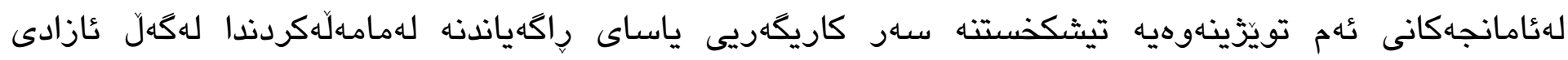
رادهربرين و مافى تايبهتمهنديدا.

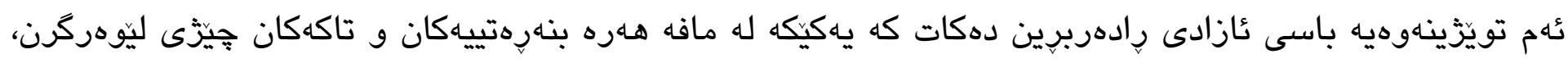

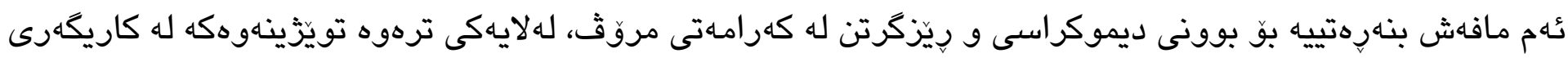


ياساى راكهياندن دهولّيتهوهو جههند نمونهيهكى سكالامهندو ناودار لهداكيركردنى ميديا بوّ تايبهتمهندى

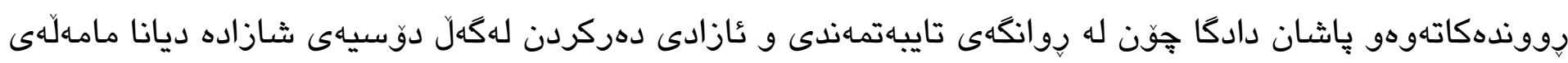
كردووه.

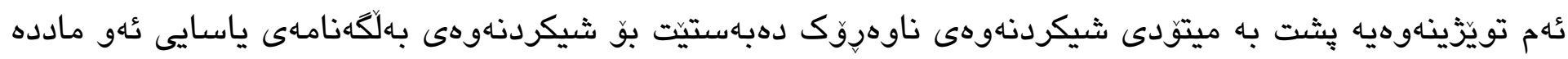

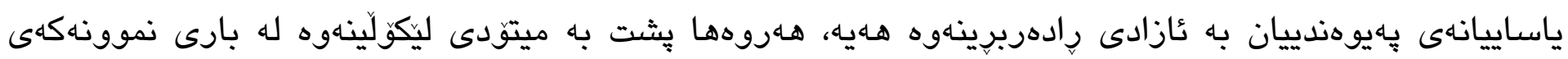
دهباهتيت كه نُهويش كهيسى شازاده ديانايه.

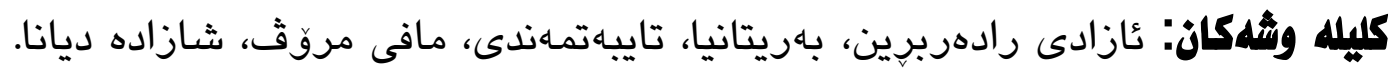




\section{References:}

Alexandru Butnaru(2020) Outlaw - Law Firm Website Template. URL: html://www.out-law.com/page4663- . \{Accessed September 01, 2020\}

Amnesty International(2014) Freedom of Expression. URL: html://www.hrea.org/learn/guides/freedom-ofexpression.html . \{Accessed 20August, 2020\}

Araz Ramazan Ahmad (2015) WHICH GOVERNMENTS MAY CONTROL THE MASS MEDIA: IRAN AND KURDISTAN AS A CASE STUDY? URL: https://doi.org/10.26458/jedep.v4i2.109 \{Accessed December 19, $2020\}$

Araz Ramazan Ahmad (2019) The Effect of Media Censorship on Freedom. URL: 10.23918/ICABEP2019p23 \{Accessed September 19, 2020\}

Aws(2017) Refining permissions in AWS using last accessed information

Baewndt, E, 2005, Freedom of Speech, 1st, United State, By Oxford University Press Inc, New York.

Beaston, J, CRIPPS, Y, 2000, Freedom of Expression and Freedom of Information, 1st, United States, By Oxford University Press Inc, New York.

Council of Europe (2020) human rights. URL: https://www.coe.int/en/web/human-rights-rule-of-law/home? \{Accessed September 17, 2020\}

Davies, P, 1988, Human Right, 1 st, United Nations, By Reprinted.

Euromedrights (2020) GENERAL QUERIES. RUL: html://www.euromedrights.net/213 \{ Accessed September $12,2020\}$

Foster, S , 2003,Human Rights and Civil Liberties, ,1st,Great Britain By Henry Ling Ltd., at the Dorset Press,Dorchester,Dorest.http://www.pcc.org.uk/cop/practice.html \{Accessed September 11, 2020\}

Human Rights Program(2020) Ways to Give. URL: html://www.kirklessrec.com/annualreport9900/humanrights.htm .\{Accessed September 01, 2020\}

Infotbel (2020) URL htpp://www.infobin.com/clank.asp?clank_id=2420\&locale=en \{Accessed 20August, 2020\} Law.cornell (2020) Human Rights. URL: https://www.law.cornell.edu/wex/human_rights \{Accessed September $12,2020\}$

Nico Krisch. (2007) The Open Architecture of European Human Rights Law. URL: html://www.leeds.ac.uk/law/htmlyn/echr.htm \{Accessed 20August, 2020\} 
Nico Krisch. (2007) The Open Architecture of European Human Rights Law. URL:

html://www.leeds.ac.uk/law/htmlyn/echr.htm \{Accessed 20August, 2020\}

NUJ (2007) highlights ongoing targeting and harassment of UK-based journalists. URL:

html://www.nuj.org.uk/inner.php?docid=1208 \{Accessed September 10, 2020\}

Parlement.UK (2007) Publications \& records. URL:

htpp://www.publications.parliament.uk/pa/cm199900/cmstand/deleg3/st000704/00704so1.html \{ Accessed 20August, 2020\}

Serendipity (2020) Human Rights. URL. html://www.serendipity.li/hr.html \{Accessed September 17, 2020\}

The Insider (2020) British regime delays Princess Diana death inquest indefinitely html://www.news.bbc.co.uk/1/hi/uk/5322932.stm. \{Accessed September 10, 2020\}

The Scotsman (2020) Labour urged to stop 'phoney war' around indyref2. URL: http:// www.news.scotsman.com \{Accessed 20August, 2020\}

Vickers, L, 2002, Freedom of speech and freedom of employment, , 1 st, Unites State, Oxford University Press Inc, New York.

Welsh, T, Greenwood, W, Banks, D, 2005, McNaeâs, Essential Law for Journalists18th Edition, United States by Oxford University PressInc, New York. 


\section{Appendices}

- ${ }^{1}$ (The Geneva conventions are a series of treaties on the treatment of civilians, prisoners of War and soldiers who are otherwise rendered hors deco bat or incapable of fighting(www.law.cornell.edu

\section{- Article 10 in Human rights Act 1998}

\section{FREEDOM OF EXPRESSION}

1. Everyone has the right to freedom of expression. This right shall include freedom to hold opinions and to receive and impart information and ideas without interference by public authority and regardless of frontiers. This Article shall not prevent States from requiring the licensing of broadcasting, television or cinema enterprises

2. The exercise of these freedoms, since it carries with it duties and responsibilities, may be subject to such formalities, conditions, restrictions or penalties as are prescribed by law and are necessary in a democratic society, in the interests of national security, territorial integrity or public safety, for the prevention of disorder or crime, for the protection of health or morals, for the protection of the reputation or rights of others, for preventing the disclosure of information received in confidence, or for maintaining the authority and impartiality of the judiciary. http://www.google.co.uk/search?hl=en\&q=article+8and+10+in+human+right+act+1998\&btnG=Google+Search\& meta $=$ last access $29 / 6 / 07$

\section{- Article 8 in Human rights Act 1998}

\section{Hum RIGHT TO RESPECT FOR PRIVATE AND FAMILY LIFE}

1. Everyone has the right to respect for his private and family life, his home and his correspondence.

2. There shall be no interference by a public authority with the exercise of this right except such as is in accordance with the law and is necessary in a democratic society in the interests of national security, public safety or the economic well-being of the country, for the prevention of disorder or crime, for the protection of health or morals, or for the protection of the rights and freedoms of others. http://www.google.co.uk/search?hl=en\&q=article+8and+10+in+human+right+act+1998\&btnG=Google+Search\& meta= last access 29/6/07 